\title{
Battery Management System with Cell Equalizer for Multi-Cell Battery Packs
}

\author{
Giovanna Oriti, Alexander L. Julian \\ Electrical and Computer Engineering Dept. \\ Naval Postgraduate School \\ Monterey, CA, USA
}

\author{
Peter Norgaard \\ Lieutenant, US Navy \\ Program Executive Office C4I \\ San Diego, CA, USA
}

\begin{abstract}
This paper describes a novel battery management system to accomplish all of the necessary functions to ensure the safe, reliable operation of lithium ion batteries. An interface circuit monitors each battery voltage and temperature. It includes a trickle charger that achieves cell balancing by active instead of passive means. A series loaded resonant converter with isolation, also known as an LLC converter, is connected to each one of the battery cells so that they can be balanced, thus increasing the lifetime and utilization of the battery stack. In this paper the battery equalizer control system is presented as well as experimental measurements on a six cell string.
\end{abstract}

\section{INTRODUCTION}

Energy storage systems have become increasingly popular with the advent of electric vehicles. They have also been used in microgrids to counteract the intermittent nature of renewable energy sources such as wind and solar [1]. In California, utilities are required to have $200 \mathrm{MW}$ of energy storage by the end of 2014 as part of the implementation of the state's ambitious renewable energy portfolio [2]. As energy storage is presently accomplished in large majority by series connected electrochemical battery cells, much attention has been given to the management of stacked battery cells. When Lithium-ion (Li-ion) battery cells are used, a battery management system (BMS) in the energy storage system is important to prevent catastrophic failures.

Cell equalizers are part of the BMS as each battery cell is not manufactured identical to the others and each cell can become overcharged or undercharged compared to the others in the stack. Cell equalizer circuits ensure that each cell maintains the same voltage, thus increasing the lifetime of the battery stack and extending the utilization of the stack. Many cell balancing methods have been proposed, both passive and active, with some of the most recent being reported in [3] through [11]. Battery balancing methods have been thoroughly reviewed and compared in [12] through [15]. Passive balancing methods are widely used for their low cost, however the energy of the overchargerd cells is dissipated as heat in resistors which reduces the efficiency and creates a heat flow challenge in the design. In this paper the active balancing method is used as part of the BMS.

There are two main types of active balancing circuits: cell-to-cell and stack-to-cell (or pack-to-cell) balancing circuits. While the cell-to-cell method moves energy from a cell with higher voltage to another with lower voltage, the stack-to-cell method exchanges energy between the individual battery cell and the entire battery stack. The latter method requires galvanic isolation and the solid state switches used have to withstand the higher voltage of the entire stack. Typical stack-to-cell equalization circuits consist of different variations of flyback converters featuring custom designed multi-winding transformers. The goal is to minimize cost by using as few solid state switches as possible, therefore only one converter is used with multiple secondary windings on its transformer. This active balancing method requires the design of a complex, custom multi-winding transformer. In this paper small resonant converters are designed for each battery cell to control its voltage. Only commercially available components are used in the design, therefore the solution has the potential of becoming cost effective. Although the switch count is higher compared to the single converter equalization circuit, the rating of the devices is a small percent of the battery charger circuit, because these small converters are used to trickle charge individual cells with just enough current to overcome cell imbalances.

The idea of using individual converters to control the voltage on each cell is new and has not been explored fully due to the perception of increased complexity. Einhorn et al. have explored the idea of individual DC/DC converters per cell, however they still use a flyback converter with individual switches on the secondaries of its transformer, therefore a custom multi-winding transformer is required [16][17]. In this paper unidirectional LLC converter modules are proposed to trickle charge the battery cells that have lower voltages. The energy comes from the stack and there is one central controller to turn on/off each converter. While a detailed cost analysis is outside the scope of this paper, 
these authors believe that there is much potential to be explored in the concept of small individual trickle-charging converters easily assembled with commercial components when compared to the custom multi-winding transformers needed in the popular flyback stack-to-cell balancing method.

Series loaded resonant converters with isolation, also known as LLC converters [18], have recently been introduced for the first time as trickle chargers for a series connected battery string [19]. While in [19] the focus is the modeling and design of each individual trickle charger, in this paper the system level control scheme is presented as well as experimental verification on a 6 cell string of lead acid batteries. The BMS can be used for Li-ion battery cells as well.

\section{BATTERY MANAGEMENT SYSTEM}

The BMS monitors each cell voltage and temperature via an interface circuit, which also includes one trickle charger per cell that achieves cell balancing by active instead of passive means. The electrical input interface includes DC power for the trickle charger, gate signals for the MOSFETS, and an enable signal and two feedback signals. The feedback signals are from $\mathrm{V} / \mathrm{f}$ converters that create a digital square wave where the frequency depends on the input voltage. The two feedback signals are the battery voltage and temperature. The interface printed circuit board can act as a mechanical mounting point for the battery cell as well. There can be a fusible link between the battery cell and the DC output to interrupt a fault current in case of a short circuit failure of the trickle charger. Since a full wave rectifier feeds the battery two diodes must fail to create a short circuit, improving reliability.
This system level architecture is attractive because one interface circuit accomplishes all of the electrical functionality necessary for battery management with the exception of the bulk charging of the battery string. The proposed solution has a separate active source for each cell which becomes more viable as the trickle charger power level gets lower and the circuits can be smaller.

The BMS comprises two key features; a charger that delivers current to the series string of batteries and individual balancing circuits that monitor and balance each battery in the string, as shown in Figure 1. The charger is the buck portion of the buck boost converter and its input is connected to an Energy Management System (EMS) which in turn interfaces with an AC bus including sources and loads [20][21]. The EMS includes the H-bridge, the buck boost converter and a field programmable gate array (FPGA) based control system. The boost portion of the charger converter is included to accomplish bidirectional power flow. In fact when power flows from the batteries to the AC bus, the boost converter ensures that the H-bridge DC bus operates at the correct voltage level. The BMS includes a balancing circuit for each battery cell in the stack which is an LLC converter as shown in Figure 2. The balancing circuit trickle charges the battery cell that it is connected to and measures the cell's voltage and temperature. The predictable behavior of the LLC converter operated in discontinuous conduction mode (DCM) provides an observer for the charging current, which is the LLC converter output current. Specifically, in DCM the converter average output current is proportional to the switching frequency as shown in (1), which is derived in [19].

$$
I_{\text {out_avg }}=\frac{4 V_{\text {stack }} f_{s w}}{\omega_{o}^{2} L_{r}}
$$

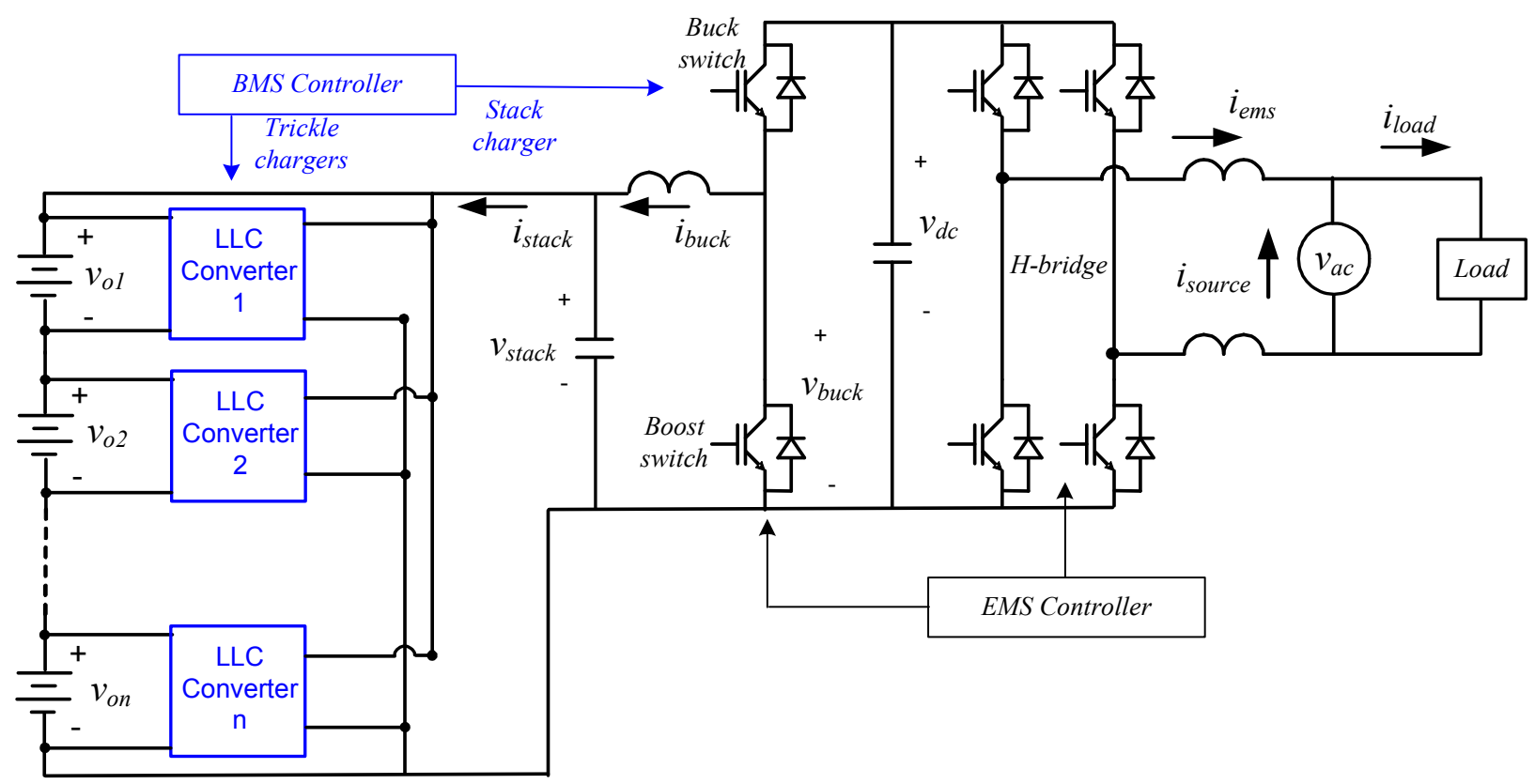

Figure 1. BMS block diagram. The LLC converter circuit is shown in Figure 2 for the cell number 4. 
where $V_{\text {stack }}$ is the input DC voltage, $L_{r}$ is the resonant inductance, $f_{s w}$ is the switching frequency $\omega_{o}$ is the resonant frequency. In DCM the relationship between the switching frequency and the resonant frequency is:

$$
f_{s w} \leq \frac{\omega_{0}}{4 \pi}
$$

The BMS software monitors all of the battery cell voltages. If any cell reaches a full state of charge (SOC) then the charger stops delivering current to the series string. The individual balancing circuits draw energy from the battery string and will trickle charge the battery cell with the lowest SOC. This process will draw some energy from the battery with the highest SOC, as well as the others in the string, to balance all of the batteries. When the balancing circuit reduces the SOC for the most charged battery, the series charger can be reenergized to deliver more energy to the battery string.

Redundant voltage measurements can be made to improve reliability. Each battery voltage is measured and additionally, the entire string voltage can be measured. The sum of the individual voltages should add up to the total voltage, which ensures the voltage sensors are operating properly. A bad voltage sensor that would cause the BMS to overcharge a battery would be a serious failure. The probability of this occurrence is reduced with a redundant voltage check.

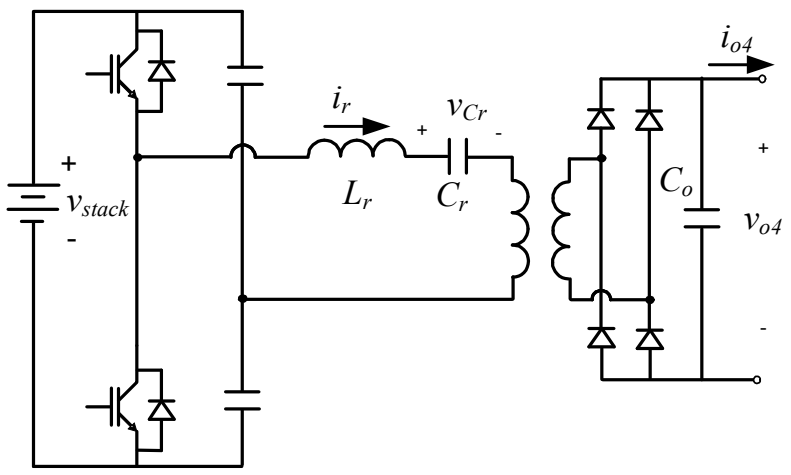

Figure 2. LLC converter used as trickle charging circuit for battery cell \#4.

Figure 3 shows the control logic implemented in the BMS to decide which LLC converter needs to be turned on or off. If a battery's voltage is lower than all the others and below the fully charged threshold minus a hysteresis band $\left(\mathrm{V}_{\text {low }}\right)$ then that battery is trickle charged and the others are turned off. If a battery gets charged up to the fully charged voltage $\left(\mathrm{V}_{\text {high }}\right)$ then its trickle charger is turned off.

The charging circuit and the balancing circuits are deenergized for about 1 second periodically so that the open circuit voltage of each battery can be observed. The measurement is put through a low pass filter and the voltage at the end of the off time is used by the BMS to decide which battery to trickle charge next. At the end of the off time the battery control algorithm trickle charges the lowest cell if it is below the full SOC voltage threshold, $\mathrm{V}_{\text {low. Also, the }}$ battery control algorithm will turn off the stack charger if any battery is at full SOC and could potentially be overcharged. This algorithm could be adapted to identify the 2 or 3 weakest batteries and trickle charge more than one at a time. This would put more loading on the battery with the highest SOC and would allow the charger to be turned back on sooner. This adaptation to the charging algorithm would realize more stored energy for later use which could improve the efficacy of the BMS. The balancing circuits need only be powerful enough to overcome any imbalance in the performance of the batteries in the string. Their most important function is to monitor the battery voltages and temperatures.

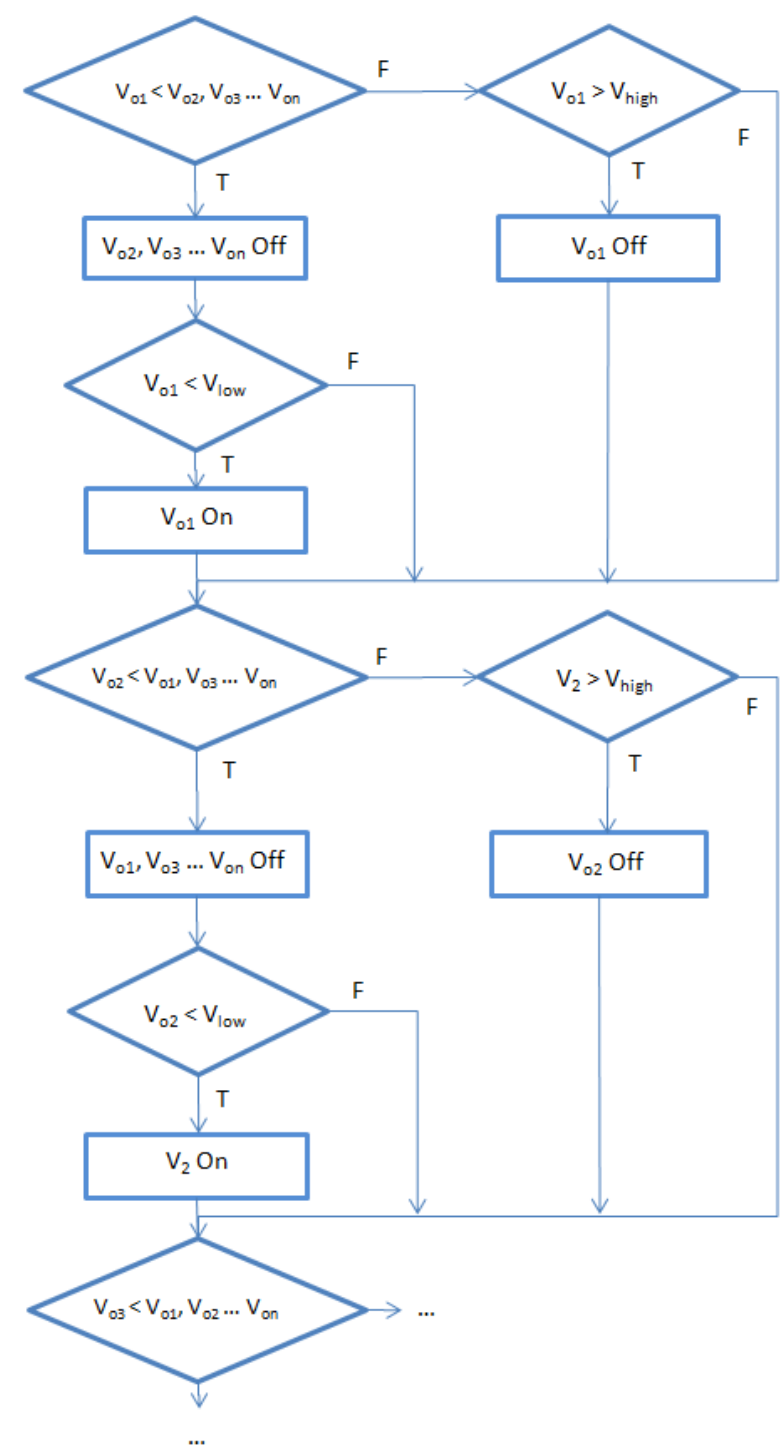

Figure 3 Battery balancing control logic.

\section{SENSOR CALIBRATION}

Precision voltage-to-frequency (V/f) converters are used to measure the voltage and temperature on each battery cell. 
The LM231 chip was used, which transforms an analog voltage (input) into a digital signal which is a square wave (output), where the frequency of the square wave is a function of the measured quantity. The comparator input to the $\mathrm{V} / \mathrm{f}$ converter, which is connected to the battery, does not load the battery measurably.

In order to calibrate the $\mathrm{V} / \mathrm{f}$ converters the outputs were each measured at 5 operating points and the data was linearized for each sensor. The plot in Figure 4 shows that each sensor needs to be calibrated to ensure accurate voltage observations are input to the BMS control algorithm. In this case the sensor on the $6^{\text {th }}$ board varies from the other 5 sensors the most.

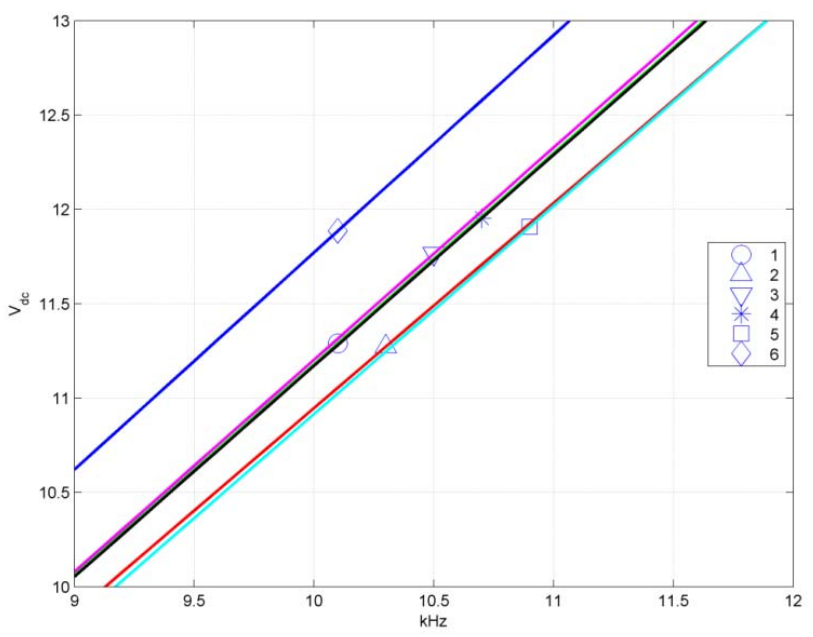

Figure 4. Linearized measured data for each V/f converter.

\section{EXPERIMENTAL MEASUREMENTS}

The operation of the BMS was verified in the lab using the system depicted in Figure 1 and described in section II. All the control features described in the previous section are implemented in a field programmable gate array (FPGA). The circuit schematic of each LLC converter used for trickle charging is shown in Figure 2 and the circuit parameters are reported in TABLE I. Six $12 \mathrm{~V}$ lead acid batteries connected in series make up the battery stack, with a nominal voltage of $72 \mathrm{~V}$. Although lead acid batteries are used in the lab for the experiments, the BMS system is being developed for $\mathrm{Li}$-ion battery packs.

TABLE I. LLC CIRCUIT PARAMENTERS

\begin{tabular}{|l|l|l|}
\hline Parameter & Symbol & Value \\
\hline Resonant capacitors & $C_{r}$ & $20 \mathrm{nF}$ \\
\hline Resonant inductor & $L_{r}$ & $35 \mu \mathrm{H}$ \\
\hline Output capacitor & $C_{o}$ & $18.8 \mu \mathrm{F}$ \\
\hline Magnetizing inductance & $L_{m}$ & $3.76 \mathrm{mH}$ \\
\hline Transformer turns ratio & $N_{t}$ & 1 \\
\hline Switching frequency & $f_{s w}$ & $24.5 \mathrm{kHz}$ \\
\hline
\end{tabular}

The AC source shown in Figure 1 provides the energy to charge the batteries in the experiments. The control system for the buck converter charger is presented in Figure 5. A sine wave at unity power factor and $180^{\circ}$ out of phase with the AC voltage is the reference current for the charger. This reference current is labeled as $I^{*}$ in Figure 5. The current drawn from the AC source $I_{e m s}$, is subtracted from the reference current described above and the error is sent to a PI controller and PWM modulator to create the gate signals for the H-bridge inverter. Note that during charging the current $I_{e m s}$ is negative, which means it goes from the AC bus to the H-bridge.

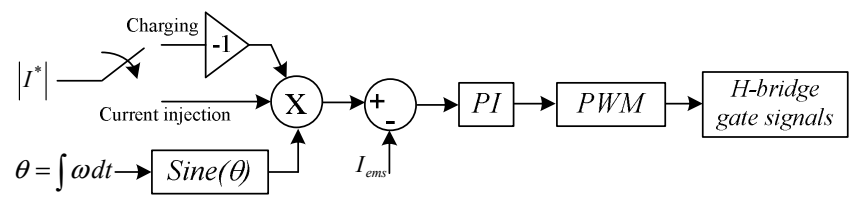

Figure 5. Control block diagram for the charger.

The DC bus is regulated by the buck converter that is charging the battery string. The amplitude of $I_{\text {ems }}$ is fixed. A PI controller adjusts the duty cycle of the buck controller to regulate the DC bus to $200 \mathrm{Vdc}$. Figure 6 shows the control system regulating the $\mathrm{DC}$ bus voltage $v_{d c}$. In the experiments presented here the DC voltage driving the buck converter is $200 \mathrm{Vdc}$.

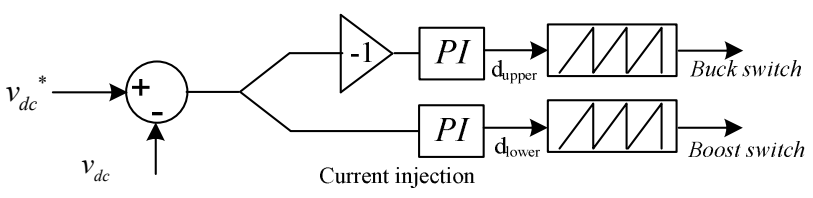

Figure 6. Control block diagram for the DC bus voltage.

The operation of the charger for the entire battery stack is demonstrated experimentally in Figure 7, Figure 8 and Figure 9. Figure 7 shows that the load is fed by the AC source and there is no EMS current $\left(I_{e m s}=0\right)$ so no energy is exchanged with the batteries. The load is inductive/resistive but there is a $12 \mu \mathrm{F}$ capacitor in parallel with the load which affects the power factor of the entire system. The waveforms acquired when the batteries are being charges are shown in Figure 8 where the current $I_{\text {ems }}$ is out of phase with the load current $I_{\text {load }}$ and the AC voltage $v_{a c}$. This indicates that power is flowing from the AC source to the battery stack. Therefore the battery stack is being charged. The load current and the source current are also shown in Figure 8, indicating that the load is not affected by the operation of the battery charger and that the source is now delivering more power in order to charge the batteries while feeding the load.

Figure 9 shows how the battery stack voltage $v_{\text {stack }}$ changes when the charger is on or off. In these plots the charger is initially on, then it turns off $\left(I_{e m s}=0\right)$ and the battery stack voltage drops about $1 / 2$ volts. After the voltages are measured it turns on again, resuming the charging of the battery stack. 

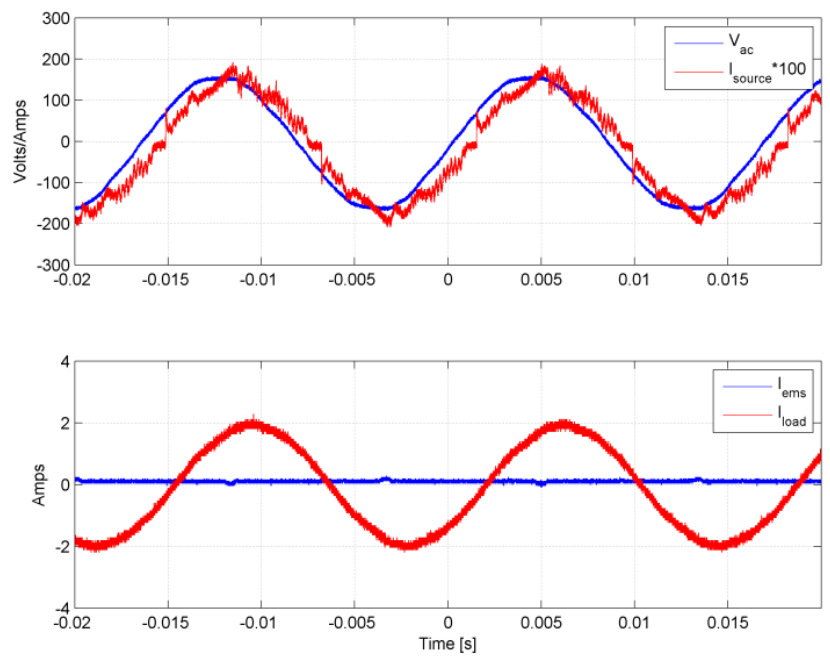

Figure 7. Experimental waveforms acquired when the AC source powers the load and the battery charger is off.
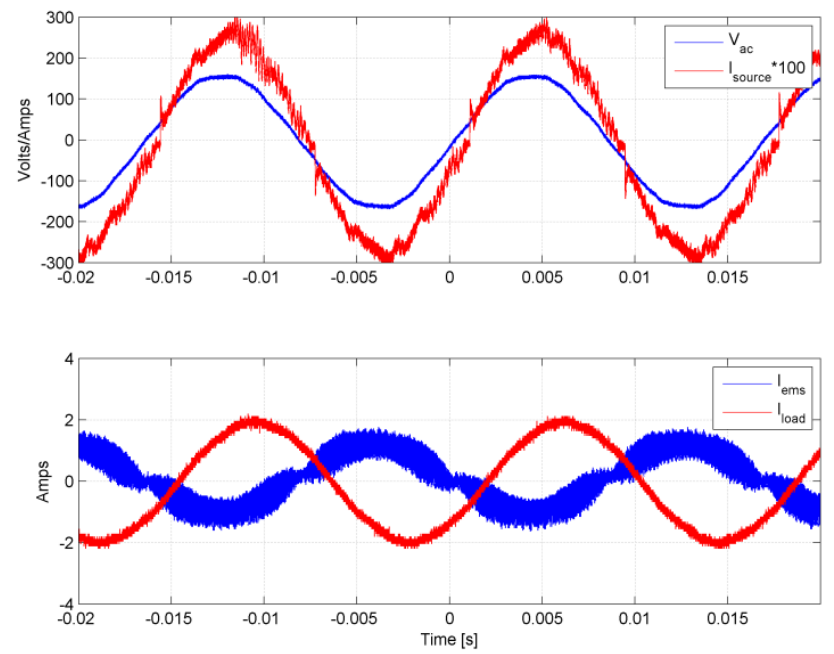

Figure 8. Experimental waveforms acquired when the AC source powers the load and the battery charger is off.
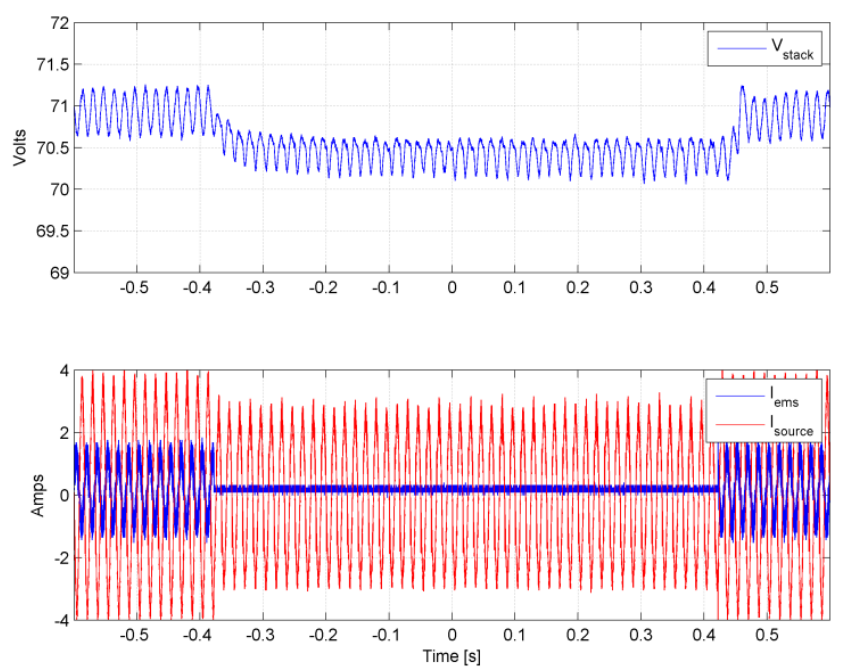

Figure 9. Experimental waveforms with charger on and off, and on again.
While the battery stack charger is off, measurements of the individual cell voltages are performed and if one is found lower than the others, then the LLC trickle charger connected to that cell is turned on by the BMS according to the logic in Figure 3. Figure 10 shows the current waveforms when both the stack charger and a single trickle charger are on. In particular the top waveform is the current going to the battery stack, while the bottom waveform is the current delivered to the battery cell $\# 4, i_{04}$. For the particular charging level demonstrated here the buck converter operates in discontinuous conduction mode, as demonstrated by the shape of the current $i_{\text {stack }}$ in Figure 10 . Note that $i_{\text {stack }}$ is not the buck converter current but the current after the capacitor.

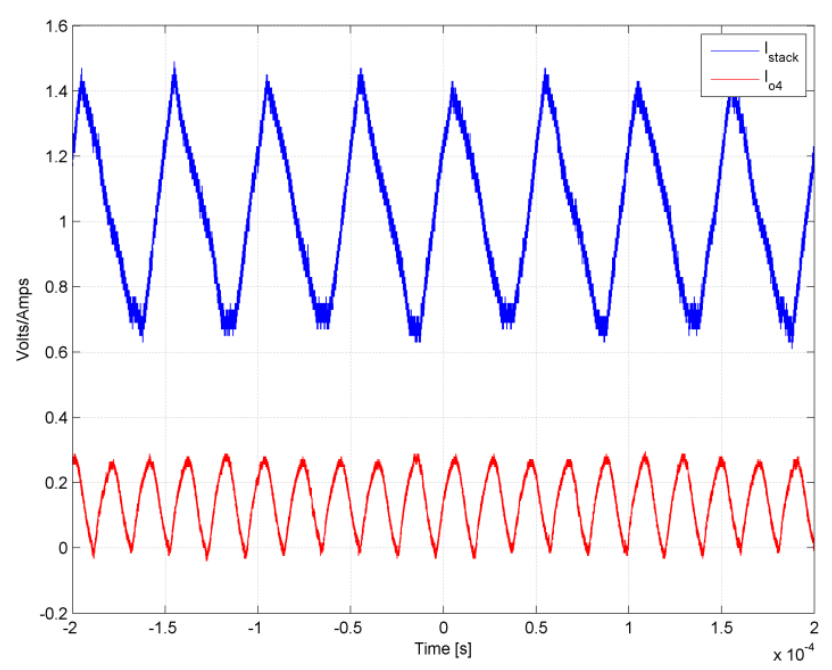

Figure 10. Experimental battery stack charging current and trickle charging current for cell $\# 4$.

The LLC converter waveforms are shown in Figure 11 for a case when the stack charger is on and only battery cell \#4 is being trickle charged. The resonant tank current $i_{r}$ demonstrates DCM. In DCM the LLC converter behaves much like a current source where the current amplitude does not change strongly as the charging voltage changes.

The leakage current of the rectifier diodes connected to the battery at the output of the LLC converter is less than 3 $\mu \mathrm{A}$ at $25^{\circ} \mathrm{C}$ and less than $70 \mu \mathrm{A}$ at $125^{\circ} \mathrm{C}$ where the voltage that the diodes block is about $12 \mathrm{Vdc}$ so the LLC converter that is always connected to the battery does not discharge the battery very much when it is not in operation.

\section{CONCLUSIONS AND FUTURE WORK}

This paper presents the hardware implementation of a novel BMS. In particular the use of small LLC converters to monitor and trickle charge each battery cell in a battery stack is the innovative contribution of this paper. The active balancing strategy improves energy conservation and provides an electrical interface to each cell to monitor the voltage and temperature, which is most important for Li-ion batteries. The BMS features simple control algorithms and easy implementation in a single FPGA. 
Reducing the complexity of the interface to a single bidirectional communication wire will be a significant enhancement to the system performance. Features that improve reliability, such as the redundant voltage check, are valuable enhancements to the system reliability. System level operation data and appropriate control laws for typical applications will help identify the most attractive battery size and balancing circuit rating to make an EMS that contains a BMS more useful.

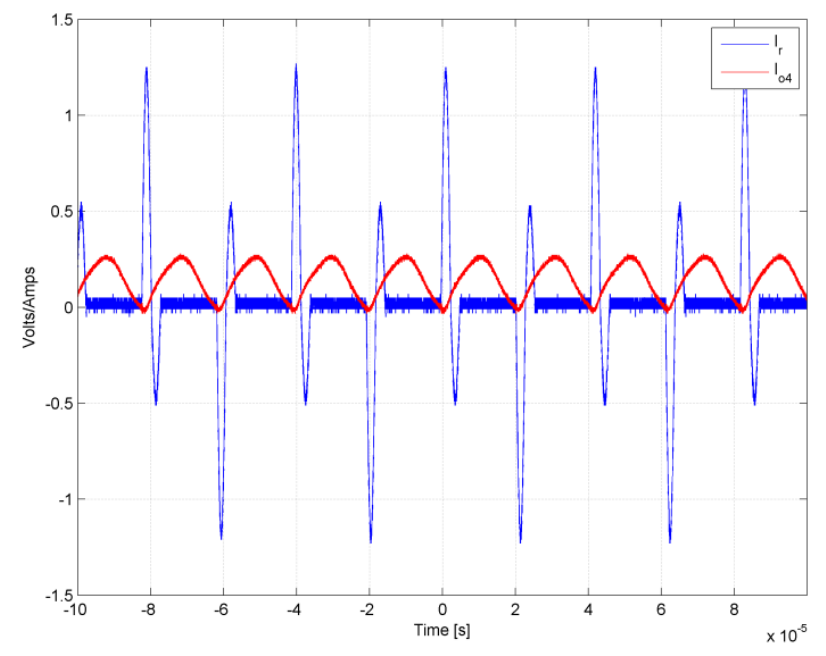

Figure 11. Experimental waveforms for LLC converter trickle charging cell \#4. The stack charger is off.

\section{REFERENCES}

[1] M. Bragard, N. Soltau, S. Thomas, R. W. De Doncker, "The balance of renewable sources and user demands in grids: power electronics for modular battery energy storage systems", IEEE Trans. Power Electron., vol. 25, no.12, Dec 2010, pp. 3049-3056.

[2] B. Sweet, "California's First-in-Nation Energy Storage Mandate", IEEE Spectrum Energywise online October 2013. Available: http://spectrum.ieee.org/energywise/energy/renewables/californiasfirstinnation-energy-storage-mandate. Accessed Nov 152013.

[3] H. Qian, J. Zhang, J-S. Lai, W. Yu, "A high efficiency grid-tie battery energy storage system", IEEE Trans. Power Electron., vol. 26, no.3, Mar. 2011.

[4] Einhorn, M.; Guertlschmid, W.; Blochberger, T.; Kumpusch, R.; Permann, R.; Conte, F.V.; Kral, C.; Fleig, J., "A Current Equalization Method for Serially Connected Battery Cells Using a Single Power Converter for Each Cell," IEEE Trans. on Veh. Technology,vol.60, no.9, pp.4227,4237, Nov. 2011.

[5] Ye Yuanmao; Cheng, K. W E; Yeung, Y. P B, "Zero-Current Switching Switched-Capacitor Zero-Voltage-Gap Automatic Equalization System for Series Battery String,", IEEE Trans. Power Electron., vol.27, no.7, pp.3234,3242, July 2012.

[6] T. Kim, W. Qiao, L. Qu, "Power electronics-enabled self-X multicell batteries: A design toward smart batteries," IEEE Trans. Power Electron., vol. 27, no. 11, pp. 4723-4733, Nov. 2012.
[7] L. Maharjan, T. Yamagishi, and H. Akagi, "Active-power control of individual converter cells for a battery energy storage system based on a multilevel cascade pwm converter," IEEE Trans. Power Electron., vol. 27,no. 3, pp. 1099-1107, Mar. 2012.

[8] C-H. Kim, M-Y. Kim, G-W. Moon, "A modularized charge equalizer using a battery monitoring IC for series-connected Li-Ion battery strings in electric vehicles", IEEE Trans. Power Electron., vol.28, no.8, p.3779-3787, Aug. 2013.

[9] Uno, M.; Tanaka, K., "Single-Switch Multioutput Charger Using Voltage Multiplier for Series-Connected Lithium-Ion Battery/Supercapacitor Equalization," IEEE Trans. Ind. Electronics,, vol.60, no.8, pp.3227,3239, Aug. 2013.

[10] A.M. Imtiaz, F.H. Khan, "Time shared flyback converter based regenerative cell balancing technique for series connected Li-Ion battery strings", IEEE Trans. Power Electron., vol.28, no.12, p.59605975, Dec. 2013.

[11] S. Yarlagadda, T. T. Hartley, I. Husain, "Battery management system using an active charge equalization technique based on a DC/DC converter topology", IEEE Trans. Ind. Appl., vol.49 no. 6, Nov/Dec. 2013, pp. 2720-2729.

[12] J. Cao, N. Schofield and A. Emadi, "Battery balancing methods: A comprehensive review", in Proc. of IEEE Vehicle Power and Propulsion Conference, (VPPC '08), 2008.

[13] S.M. Lukic, Jian Cao, R.C. Bansal, F. Rodriguez, A. Emadi, "Energy Storage Systems for Automotive Applications," IEEE Trans. on Ind. Electr., vol.55, no.6, pp.2258-2267, June 2008.

[14] M. Daowd, N. Omar, P. Van den Bossche, J. Van Mierlo, "Passive and active battery balancing comparison based on MATLAB simulation," Vehicle Power and Propulsion Conference (VPPC), 2011 IEEE, Sept. 2011, pp.1-7.

[15] W. Ch. Lee, D. Drury, P. Mellor, "Comparison of passive cell balancing and active cell balancing for automotive batteries", in Proc. of IEEE Vehicle Power and Propulsion Conference (VPPC) 2011, 6-9 Sep. 2011.

[16] M. Einhorn, W. Roessler, and J. Fleig, "Improved Performance of Serially Connected Li-Ion Batteries With Active Cell Balancing in Electric Vehicles", IEEE Trans. on Veh. Tech., vol.60 no.6, Jul 2011, pp. 2448-2457.

[17] M. Einhorn, W. Guertlschmid, T. Blochberger, R. Kumpusch, R. Permann, F. V. Conte, C. Kral, and J. Fleig, "A Current Equalization Method for Serially Connected Battery Cells Using a Single Power Converter for Each Cell", IEEE Trans. on Veh. Tech., vol.60 no.9, Nov 2011, pp. 4227-4237.

[18] B. Yang, F. C. Lee, A. J. Zhang and G. Huang, "LLC Resonant Converter for Front End DC/DC Conversion", in Proc. of Applied Power Electronics Conf. and Expo. 2002. (APEC 2002), pp. 1108 1112 vol.2.

[19] A.L. Julian, G. Oriti, M.E. Pfender, "SLR Converter Design for Multi-Cell Battery Charging", in Proc. of the IEEE 5th Energy Conversion Conference and Expo (ECCE) 2013, Denver, CO, Sep 2013.

[20] G. Oriti, A.L. Julian, N.J.Peck, "Power Electronics Enabled Energy Management Systems", in Proc. of IEEE Appl. Power Elec. Conf. and Expo (APEC) 2013, Long Beach, CA, March 2013.

[21] R. L. Kelly, G. Oriti, A. L. Julian, "'Reducing fuel consumption at a remote military base: introducing an energy management system", IEEE Electrification Magazine, vol.1 , no.2, Dec 2013, pp. 30-37. 